\title{
Market Orientation, Firm Performance And The Mediating Effect Of Corporate Social Responsibility
}

\author{
Roshayani Arshad, Accounting Research Institute, Universiti Teknologi MARA, Malaysia \\ Siti Mariam Mansor, Universiti Teknologi MARA, Malaysia \\ Rohana Othman, Accounting Research Institute, Universiti Teknologi MARA, Malaysia
}

\begin{abstract}
This study examines the effect of CSR disclosure and MO on firm performance as well as the mediating effect of CSR on the relationship between $M O$ and firm performance. These relationships are examined based on content analysis of 242 Malaysian public listed companies' annual reports for 2006, 2007 and 2008. Results of this study provide evidence that CSR activities communicated in corporate annual reports are important business strategy in creating continuous superior performance for organisations. The results also indicate that $M O$ companies are integrating CSR activities into their business strategies. However, the insignificant mediating effect of CSR on the relationship between MO and firm performance indicates that MO and CSR strategies have not been effectively integrated in creating a synergistic effect that can bolster firm performance. Overall, findings in this study indicate the strategic value of CSR in creating economic sustainability for organizations even in an environment characterised by concentrated ownership structure where the companies may be less market focused.
\end{abstract}

Keywords: Corporate Social Responsibility; Market Orientation; Firm Performance; Mediating Effect

\section{INTRODUCTION}

ncreasing awareness on the role of business in society and the nature of a firm's social responsibilities has led to greater political and social demands for companies to increase their social activities. As such, managers are confronted with corporate social responsibility (CSR) issues that can meet the demands of various stakeholders. As an organisation operates within a network of different stakeholders who can influence the organisation directly or indirectly, the ability of managers in managing their CSR activities is a strategic issue for an organisation (Galbreath, 2008). Failure to meet the demands of various stakeholders can lead to withdrawals of support and consequent adverse effects on firm's performance. This implies that addressing societal expectations is an important consideration for competitive success in order to achieve economic sustainability for organisations.

Prior studies have reported inconclusive results on the relationships between CSR and firm performance (e.g. Griffin \& Mahon, 1997; Iwata \& Okada, 2011; Margolis \& Walsh, 2003). Nevertheless, more recent studies have documented positive relationships between CSR and firm performance (Iwata \& Okada, 2011; Sueyoshi \& Goto, 2011). This in turn suggests that CSR is an important corporate resource that can be a source of competitive advantage (Piercy \& Lane, 2009). From a business strategy perspective, CSR can be a tool that integrates and balances organisational responsibilities to the various stakeholders (Maignan et al., 2005). This is in line with the emerging concern raised in the marketing and strategic management literature that business strategies of organisations should not only focus on their customers but also other stakeholders that they are accountable for (Maignan et al, 2005). While CSR is an important consideration in the formulation of effective business strategies, much confusion still remains with respect to integration of CSR into the overall business strategy (Galbreath, 2008). 
A large body of research has examined the link between business strategy and firm performance through market orientation (MO) perspective (e.g. Kohli \& Jowarski, 1990; Kircha et al., 2005 and Narver \& Slater, 1990). This perspective argues that organisations gain competitive success by effectively serving dominant stakeholders and meeting the changing needs of the market (Narver \& Slater, 1990). This perspective is congruent with CSR initiatives and research on the synergistic effects of CSR and MO on firm performance with focused on companies that operate in developed countries (Maignan et al., 2005). However, there is limited research on the strategic value of CSR, MO and firm performance in developing countries even though there is an increasing trend in the adoption of market orientation and CSR initiatives by organizations in this economy (e.g. Anis et al., 2010, Qu, 2009). In addition, these literatures argue that organisations in developing countries tend to adopt strategic actions in a piecemeal basis and this can lead to ineffective integration of various strategies. Hence, it is timely to examine the link between CSR, MO and firm performance.

The objective of this study is first to provide evidence on the relationships between CSR and MO on firm performance for Malaysian public listed companies. The second and more substantial objective is to examine whether CSR is a link between MO and firm performance. Findings in this study will add to the limited insight on these relationships in developing countries.

This paper will proceed with the motivation for the study and review of past literature from which hypotheses will be developed. The paper will then proceed to the empirical stage of variable measurement, sampling, data analysis and discussion of results. The final part of this paper presents conclusion, limitations and suggestions for future research.

\section{LITERATURE REVIEW AND HYPOTHESES DEVELOPMENT}

\section{CSR Disclosure And Firm Performance}

The stakeholder theory suggests that when corporations meet the expectations of various stakeholders, they are more capable in creating superior firm performance (Freeman, 1984). Prior literature on CSR (e.g. Deegan, 2002; Gray et al., 1995 and Galbreath, 2010) has highlighted that CSR has become an important drivers in influencing stakeholders' opinion regarding fulfilment of corporate obligations. These literatures argue that stakeholders tend to incorporate their expectations into their behaviour towards the company. Failure to communicate their CSR could lead to potential withdrawals of support from the stakeholders and consequent adverse effects on firm's performance. Hence, it is paramount that companies communicate their CSR activities in order to potray that they are fulfilling the stakeholders' expectations. While it is not possible to meet the needs of every stakeholder in a society, Maignan et al., (2005) suggest that stakeholders refer to those who are directly or indirectly affect or affected by the firm's activities. In communicating CSR activities, many companies are using their annual reports as a medium of disclosure (e.g. Deegan 2002 and Galbreath, 2010).

The stakeholder theory perspective suggests that it is paramount for companies to move beyond market transactions gain in order to achieve superior performance in their business. While companies in developed countries have incorporated CSR practices into their business strategies, companies in developing countries often lag behind their developed countries' counterparts (KPMG, 2005). However, in the advent of globalization, rising consumer expectations towards business conduct and emergence of regulatory efforts promoting CSR practices, companies in developing countries are expected to recognize the strategic importance of CSR practices. In Malaysia, the emphasis on CSR initiatives and disclosure by various regulatory efforts are expected to shift stakeholders' expectations towards expecting more CSR initiatives. This in turn increases pressure on companies to increase their CSR disclosures. The potential increase in the disclosure of CSR activities are expected to improve stakeholder relations and consequently improve firm performance. While prior studies have reported inconclusive results on the relationships between CSR and firm performance (e.g. Griffin \& Mahon, 1997 and Margolis \& Walsh, 2003), this study expects a positive relationship. This is based on the argument that in a business environment where various stakeholders have high expectations of companies' CSR, managers are expected to acknowledge the strategic importance of CSR and accordingly implement CSR activities in order to improve performance (Qu, 2009). In addition, managers are also expected to take more direct and visible steps to communicate their CSR initiatives. This leads to the following hypothesis: 
H1: The extent of CSR disclosure is significantly positively related to firm performance.

\section{MO And Firm Performance}

The marketing and strategic management literature highlights that $\mathrm{MO}$ is an important consideration in the implementation of business strategies (Kohli \& Jowarski, 19901). According to Narver \& Slater (1990), MO refers to the organisational culture that most effectively and efficiently creates the necessary behaviour for the creation of continuous superior performance for the business. They posited that performance-related behaviour includes customer orientation, competitor orientation and interfunctional coordination. In other words, organisations need to take proactive attitude in doing business and be responsive to customer needs and market changes in order to remain competitive. As such, market-oriented companies are more capable in developing superior strategies and efficient resource allocation that can enhance value creation. Consistent with this argument, past literatures indicated that market-oriented companies achieve better firm performance relative to those less market-oriented. (e.g. Kohli \& Jowarski, 1990; Kircha et al., 2005 and Narver \& Slater, 1990). Some researchers argue that this relationship is context specific and may not be generalised across countries with different institutional environment (e.g. Kim, 2003; Tse et al., 2001). However, more recent studies have documented the positive impacts of MO on firm performance in non-US contexts, indicating potential generalisability of the theoretical arguments and applications.

Recognition of market focus is central to the concept of MO. While past literature suggests generalisability of the theoretical model of MO across cultural and environmental differences, the level of MO may vary due to these differences (Tse et al., 2001). For instance, organisations operating in highly regulated and governmentinvolved economy may be less market focused relative to those operating in free market economy. In addition, companies characterised by concentrated ownership structure and the existence of dominant owners with excessive control over the board of directors, particularly in East Asian countries, may be risk-averse with preference of lowrisk projects. Such projects can be less responsive to customer demands and market changes. As such, the MO of these companies becomes weaker. In Malaysia, there has been a continuous regulatory effort towards a market economy even though government and family owned companies represent a substantial percentage of companies listed on the stock exchange (e.g. Haniffa \& Cooke, 2002; Nazli \& Weetman, 2006). One of the objectives of the New Economic Model for Malaysia which was unveiled in 2010 is moving Malaysia towards a competitive and developed nation. This is expected to result in higher level of MO perspectives among organisations in Malaysia and in turn is expected to enhance firm performance. Based on this reasoning, the following hypothesis is developed:

H2: Market oriented companies are significantly positively related to firm performance.

\section{The Mediating Effect Of CSR On MO And Firm Performance}

The above arguments highlights that CSR has a growing influence on business strategies, particularly in terms of its impact on firm performance. According to Porter (1996), business strategies refer to the various actions taken by organisations so that they can respond accordingly to the changes in their environment and subsequently create superior performance. Hence, it is imperative that organizations adapt quickly to any changes in their business environment.

To date, corporate strategies are moving from customer orientation to managing relationships that provide benefits to all relevant stakeholders (Maignan et al, 2005). Relevant stakeholders in this context refer to those who affect or are affected by the firm's activities. In meeting the demands and needs of relevant stakeholders, an organisation needs to constantly adapt to the changes in environment in order to achieve competitive success. In Malaysia, the emphasis by regulatory bodies and policy makers on CSR activities is expected to shift investors and other stakeholders' expectations toward expecting more CSR initiatives. This in turn requires companies to integrate appropriate and relevant CSR initiatives that meet the demands of relevant stakeholders into their business strategies. Based on this argument, it is expected that market-oriented companies in Malaysia are more likely to meet the diverse needs of various stakeholders and consequently have a positive impact on their firm performance. This leads to the following hypothesis:

H3: CSR mediates the positive relationship between $\mathrm{MO}$ and firm performance. 


\section{METHODOLOGY}

\section{Sample And Data Collection}

The sample was drawn from non-financial companies listed on the main Board of Bursa Malaysia for the year 2006, 2007 and 2008. 242 companies with financial year ending 31 December were randomly selected. This is to eliminate the element of bias in the selection process. A three-year window period enables an examination of the hypothesised relationships in period before, during and after the mandatory CSR disclosure became effective in 2007 in Malaysia. For the three years sampled, the sample comprised 726 cases. The research approach involves the content analysis of listed companies' published annual reports. Content analysis has been widely employed in prior studies to measure CSR disclosure (e.g. Hackston \& Milne, 1996; Smith et al., 2005).

\section{Level Of Market Orientation}

The level of MO in this study is measured using a self constructed index MO. MO is based on the aggregate score of behavioural characteristics of MO adapted from Narver \& Slater (1990) and Kohli et al., (1993). Narver \& Slater (1990) focus on three behavioural characteristics; customer orientation, competitor orientation and interfunctional coordination, while Kohli et al., (1993) focus on behavioural activities which are classified as intelligence generation, dissemination and responsiveness. According to Mavondo and Farrell (2000), these characteristics are similar and as such can be integrated in measuring MO. In searching for the behavioural characteristics of MO, all sections of annual reports were searched, including notes to the financial statements, chairman's statement and directors' report. The level of MO is measured by comparing the contents of each annual report to the items in the index and coded as " 1 " if the item is disclosed and " 0 " if not. As in previous studies, disclosure item considered as not applicable to a company will not be penalized. Further, in assessing the applicability of a particular item, the entire annual report will be read to be reasonably certain that no similar information can be found in any part of the annual reports before a judgement is made on this matter.

For each company, the MO index score is calculated as a ratio of the actual score awarded to the company divided by the maximum potential score awarded to that company. The MO index used for each company in order to measure the level of MO is calculated as follows:

$\mathrm{MO}_{j}=\frac{\sum_{\mathrm{i}=1}^{n_{j}} \mathrm{X}_{i j}}{n_{j}}$

Where $n_{j}=$ number of items expected for $j^{\text {th }}$ company, $n_{j}$ is $\leq 10$,

$X_{i j} \quad=1$ if $i^{\text {th }}$ item disclosed and 0 if $i^{\text {th }}$ item not disclosed,

So that $0 \leq I_{j} \geq 1$

The total score $\mathrm{MO}_{j}$ represents the number of points awarded to company $j$ and it is an ordinal measure of the level of MO for each company. The score is additive and unweighted. Unweighted scores are used in this study for several reasons. First, the use of unweighted index assumes that each item disclosed by a company is of equal importance to the relevant stakeholders' decision-making process. Second, using a weighted disclosure index will involve assigning weights to reflect the importance of certain types of information (Chow \& Wong-Boren, 1987). The degree of importance is generally based on rankings obtained from pooled opinions of a group of subjects (analysts or any preferred user group). The subjective judgements involved in assigning the weights (Gray et al., 1995) reduces the objectivity of the index as a measure of the extent of MO disclosure. Further, Chow \& WongBoren (1987) suggest that the use of weighted or unweighted disclosure index is interchangeable because they find almost equivalent results using either one of the index. Finally, the scoring approach using unweighted disclosure index in this study is also supported by the approach employed and adopted in several prior studies on disclosures (e.g Gray et al., 1995 and Haniffa \& Cooke, 2005). 


\section{Measurement Of Variables}

There are two independent variables in this study, level of MO and extent of CSR disclosure. The measurement for the level of MO is as explained in the previous section. The second independent variable, CSR is based on the aggregate number of words related to CSR disclosure in annual reports. Various recording units have been used by content analysis researchers to measure the extent of corporate disclosures. For example, Deegan \& Rankin (1996) and Wilmshurst \& Frost (2000), use word count while researchers such as Guthrie \& Parker (1989) use number of pages and Deegan et al. (2002) use number of sentences as the unit of analysis. According to Gray et al. (1995), there is some uncertainty as to the optimal measure of the extent of disclosure, with words, sentences and pages being the preferred units of analysis for written communication. Unerman (1999)'s finding indicates that testing content analysis using any of the above units resulted in insignificant difference. Following Haniffa and Cooke (2005), graphical presentation of CSR activities were excluded from the word count in this study. In addition to the identified independent variables, this study also includes two firm characteristics identified in prior research as determinants of management disclosure decisions (e.g. Gray et al., 1995; Haniffa \& Cooke, 2005) as control variables. These variables are size and leverage. The definition and measurement of variables used in this study are listed in Table 1.

Table 1: Definition and Measurement of Variables

\begin{tabular}{|l|l|l|}
\hline \multicolumn{1}{|c|}{ Variable Acronym } & \multicolumn{1}{|c|}{ Definition } & \multicolumn{1}{c|}{ Measurement } \\
\hline RET & Firm performance & $\begin{array}{l}\text { Stock returns based on the average of the } \\
\text { end of the four quarters of stock prices }\end{array}$ \\
\hline CSR & The extent of CSR disclosure & Number of words counted \\
\hline MO & Level of market orientation & Self constructed market orientation index \\
\hline SIZE & Firm size & Total assets \\
\hline LEV & Leverage & Total liabilities divided by total assets \\
\hline
\end{tabular}

\section{ANALYSIS AND RESULTS}

\section{Descriptive Statistics}

Table 2 presents the descriptive statistics on dependent variable of firm performance, which is represented by the stock returns (RET) over the period of three years under study. The results of descriptive statistics for continuous independent variables and control variables are presented in Table 3.

Table 2: Descriptive Statistics for Stock Returns (RET) in 2006, 2007 and 2008

\begin{tabular}{|l|c|c|c|c|c|c|c|c|c|}
\hline & \multicolumn{3}{|c|}{ Maximum } & \multicolumn{3}{c|}{ Minimum } & \multicolumn{3}{c|}{ Mean } \\
\cline { 2 - 10 } & $\mathbf{2 0 0 6}$ & $\mathbf{2 0 0 7}$ & $\mathbf{2 0 0 8}$ & $\mathbf{2 0 0 6}$ & $\mathbf{2 0 0 7}$ & $\mathbf{2 0 0 8}$ & $\mathbf{2 0 0 6}$ & $\mathbf{2 0 0 7}$ & $\mathbf{2 0 0 8}$ \\
\hline RET(\%) & 5787.87 & 9931.11 & 9559.21 & 0.23 & 0.31 & 0.28 & 3.61 & 5.33 & 4.69 \\
\hline
\end{tabular}

Table 2 reported that RET ranges from a minimum of $0.23 \%$ to $5787.87 \%$ in $2006,0.31 \%$ to $9931.11 \%$ in 2007 and $0.28 \%$ to $9559.21 \%$ in 2008 . The mean value of RET indicates an increase from $3.61 \%$ in 2006 to $5.33 \%$ in 2007 , even though the trend decreases slightly to $4.69 \%$ in 2008 .

Table 3: Descriptive Statistics for Independent and Control Variables

\begin{tabular}{|l|c|c|c|c|c|c|c|c|c|}
\hline & \multicolumn{3}{|c|}{ Maximum } & \multicolumn{3}{|c|}{ Minimum } & \multicolumn{3}{c|}{ Mean } \\
\cline { 2 - 11 } & $\mathbf{2 0 0 6}$ & $\mathbf{2 0 0 7}$ & $\mathbf{2 0 0 8}$ & $\mathbf{2 0 0 6}$ & $\mathbf{2 0 0 7}$ & $\mathbf{2 0 0 8}$ & $\mathbf{2 0 0 6}$ & $\mathbf{2 0 0 7}$ & $\mathbf{2 0 0 8}$ \\
\hline CSR words) & 4803.00 & 4313.00 & 9942.00 & 0.00 & 0.00 & 0.00 & 251.88 & 576.25 & 807.93 \\
\hline MO (\%) & 100 & 100 & 100 & 10 & 10 & 10 & 54.88 & 52.19 & 49.01 \\
\hline LEV (ratio) & 0.76 & 0.76 & 0.79 & 0.00 & 0.00 & 0.00 & 0.22 & 0.21 & 0.22 \\
\hline Size (mil) & 103.00 & 67.72 & 69.84 & 0.06 & 0.07 & 0.06 & 2.14 & 2.14 & 2.25 \\
\hline
\end{tabular}


Table 3 reported that the level of CSR disclosure on average has increased from 251.88 words in 2006 to 807.93 words in 2008. A possible explanation is that the CSR mandatory disclosure requirements have induced companies to increase their CSR disclosure in annual reports. As for the independent variable of MO, the minimum value was $10 \%$ while the maximum value was $100 \%$ for all the three sampled years. This implies that the level of MO is fairly stable during these periods. Of the control variables, Table 3 documented that the mean value of LEV is $22 \%$ in $2006,21 \%$ in 2007 and $22 \%$ in 2008. Size ranges from a minimum of RM2.14 million in 2006 to RM2.25 million in 2008, while the maximum value decreases from RM103 million in 2006 to RM69.84 million in 2008.

\section{Multivariate Analysis}

In this study, linear multiple regression is used as the basis of analysis for testing H1 to H3. The hypothesized relationships for $\mathrm{H} 1$ and $\mathrm{H} 2$ respectively are modeled as follows.

Model 1(test of H1):

$\mathrm{RET}=\beta_{0}+\beta_{1} \mathrm{MO}+\beta_{2} \mathrm{LEV}+\beta_{3} \mathrm{SIZE}+\varepsilon_{\mathrm{t}}$

Model 2(test of $\mathrm{H} 2$ ):

RET $=\beta_{0}+\beta_{1}$ CSR $+\beta_{2}$ LEV $+\beta_{3}$ SIZE $+\varepsilon_{t}$

where variable definitions are given in Table 1 .

In the above regression models, multicollinearity was tested using the variance inflation factor and tolerance levels, and found to be well within the satisfactory range. The results of the regression analysis are presented in Table 4 and are now discussed in terms of tests of each of the hypotheses.

Table 4: Multiple Regression Results For CSR Disclosure

\begin{tabular}{|c|c|c|c|c|c|c|}
\hline \multicolumn{7}{|c|}{ Dependent variable: RET (Stock Returns) } \\
\hline & \multicolumn{2}{|c|}{2006} & \multicolumn{2}{|c|}{2007} & \multicolumn{2}{|c|}{2008} \\
\hline & Beta & t-value & Beta & t-value & Beta & t-value \\
\hline \multicolumn{7}{|l|}{ Constant } \\
\hline CSR & $0.228 * * *$ & 2.975 & $0.181 * * *$ & 2.811 & $0.226 * * *$ & 3.631 \\
\hline LEV & $-0.384 * * *$ & -6.217 & $-0.312 * * *$ & -5.031 & $-0.323 * * *$ & -5.333 \\
\hline SIZE & $0.329 * * *$ & 4.984 & $0.389 * * *$ & 5.917 & $0.375 * * *$ & 5.737 \\
\hline Adj. $\mathbf{R}^{2}$ & \multicolumn{2}{|l|}{0.259} & \multicolumn{2}{|l|}{0.253} & \multicolumn{2}{|l|}{0.280} \\
\hline $\mathbf{F}$ & \multicolumn{2}{|l|}{$29.065 * * *$} & \multicolumn{2}{|l|}{$28.246 * * *$} & \multicolumn{2}{|c|}{$32.271 * * *$} \\
\hline
\end{tabular}

Coefficient for each variable is shown with $\mathrm{t}$ values in parentheses. * Significant at 10 per cent level (1-tailed test);

$* *$ Significant at 5 per cent level (1-tailed test);*** Significant at 1 per cent level (1-tailed test)

Results of the multiple regression analysis in Table 4 report that the adjusted $R^{2}$ is 0.259 in $2006,0.253$ in 2007 and 0.280 in 2008. H1 predicts that the extent of CSR disclosure is significantly positively related to stock returns (RET). The results in Table 4 reveal a positive relationship for the three years. It is possible that managers in Malaysia foresee significant value additions in firm performance associated with strengthened stakeholders' relation resulting from their CSR initiatives. This is also consistent with the inference that CSR is an important corporate resource that can be a strategic tool in meeting relevant stakeholders' expectations in order to achieve economic sustainability for organisations. Consequently, more direct and visible steps are taken by managers in communicating their CSR initiatives in annual reports even during the period before mandatory disclosure requirements became effective. This in turn has a positive impact on firm performance as reflected in the valuation of the company by investors. Based on these results, $\mathrm{H} 1$ is accepted.

$\mathrm{H} 2$ hypothesised that MO has a positive effect on firm performance. However, the results in Table 5 reveal negative insignificant relationships between MO and RET for the three sample years. Hence, $\mathrm{H} 2$ is rejected. This infers that the level of $\mathrm{MO}$ among the companies is not sufficient to induce performance-related behaviours among the managers. Such behaviour can be influenced by the level of uncertainty in the market environments where the companies are operating (Slater \& Narver, 1990). In Malaysia, market environment characterised by concentrated 
ownership structure increases the level of uncertainty through low transparency and this can influence managers to minimise the uncertainty by engaging in building personal relationships with governmental bodies and other resource suppliers (e.g. Sin \& Tse, 2001; Slater \& Narver, 1990). In addition, the presence of dominant owners with controls over the overall business strategies of organisation further reduces market-oriented behaviours among the managers that are important in the creation of continuous superior performance for the companies. Consequently, managers in this environment perceived that MO is a less important business strategy and this is corroborated with the consistent level of MO among the sample years reported in Table 4 on analysis of descriptive statistics.

Table 5: Multiple Regression Results For Level Of MO

\begin{tabular}{|l|c|c|c|c|c|c|}
\hline \multicolumn{7}{|c|}{ Dependent variable: RET (Stock Returns) } \\
\hline & \multicolumn{2}{|c|}{$\mathbf{2 0 0 6}$} & \multicolumn{2}{c|}{$\mathbf{2 0 0 7}$} & \multicolumn{2}{c|}{$\mathbf{2 0 0 8}$} \\
\hline Constant & 0.007 & 0.129 & 0.005 & 0.095 & 0.005 & 0.092 \\
\hline MO & -0.068 & -1.156 & -0.044 & -0.722 & -0.050 & -0.842 \\
\hline LEV & $-0.432 * * *$ & -6.960 & $-0.351 * * *$ & -5.696 & $-0.363 * * *$ & -5.942 \\
\hline SIZE & $0.431 * * *$ & 7.254 & $0.480^{* * *}$ & 7.962 & $0.487 * * *$ & 8.222 \\
\hline Adj. $\mathbf{R}^{\mathbf{2}}$ & 0.236 & & 0.230 & & 0.243 & \\
\hline F & $25.765 * * *$ & & $25.017 * * *$ & & $26.727 * * *$ & \\
\hline
\end{tabular}

Coefficient for each variable is shown with t values in parentheses. * Significant at 10 per cent level (1-tailed test);

$* *$ Significant at 5 per cent level (1-tailed test);*** Significant at 1 per cent level (1-tailed test)

Regression Analysis For Mediating Variable (Test Of Hypothesis 3)

H3 predicts that CSR mediates the relationship between MO and firm performance. Following Baron \& Kenny (1986), the following conditions must be met in testing the mediating effect of CSR:

1. MO has significant effect on CSR disclosure,

2. CSR disclosure has significant effect on RET,

3. MO has significant effect on RET, and

4. When CSR enter the regression model, the significant effect of MO on RET decreases substantially for partial mediation and become insignificant for full mediation.

Conditions 2 and 3 have been tested based on Model 1 and Model 2 discussed earlier, where condition 2 was satisfied and condition 3 was not. Conditions 1 and 4 are examined based on the following models:

Model 3:

$\mathrm{CSR}=\beta_{0}+\beta_{1} \mathrm{MO}+\beta_{2} \mathrm{LEV}+\beta_{3} \mathrm{SIZE}+\varepsilon_{\mathrm{t}}$

Model 4:

$\mathrm{RET}=\beta_{0}+\beta_{1} \mathrm{MO}+\beta_{2} \mathrm{CSR}+\beta_{3} \mathrm{LEV}+\beta_{4} \mathrm{SIZE}+\varepsilon_{\mathrm{t}}$

The results for Model 3 and Model 4 are presented in Table 6 and Table 7 respectively.

Table 6: Multiple Regression Results for Model 3

\begin{tabular}{|l|c|c|c|c|c|c|}
\hline & \multicolumn{2}{|c|}{$\mathbf{2 0 0 6}$} & \multicolumn{2}{c|}{$\mathbf{2 0 0 7}$} & \multicolumn{2}{c|}{$\mathbf{2 0 0 8}$} \\
\hline & Beta & t-value & Beta & t-value & Beta & t-value \\
\hline Constant & 0.068 & 1.513 & 0.012 & 0.231 & 0.001 & 0.014 \\
\hline LEV & $-0.142 * * *$ & -2.791 & $-0.188^{* * *}$ & -3.145 & $-0.163 * * *$ & -2.732 \\
\hline SIZE & $0.393 * * *$ & 8.107 & $0.432 * * *$ & 7.398 & $0.494 * * *$ & 8.554 \\
\hline MO & $0.146 * * *$ & 3.016 & $0.190 * * *$ & 3.225 & $0.259 * * *$ & 4.481 \\
\hline Adj. R & 0.247 & & 0.232 & & 0.273 & \\
\hline F & $27.409 * * *$ & & $25.255^{*} * *$ & & $31.096 * * *$ & \\
\hline
\end{tabular}

Coefficient for each variable is shown with $t$ values in parentheses. * Significant at 10 per cent level (1-tailed test);

** Significant at 5 per cent level (1- tailed test); *** Significant at 1 per cent level (1-tailed test)

(C) 2012 The Clute Institute http://www.cluteinstitute.com/ 
The results in Table 6 revealed significant positive relationships between MO and CSR for the years 2006, 2007 and 2008. Hence, condition 1 is met. These results are consistent with the view that market-oriented companies are more sensitive and responsive in meeting the needs of the relevant stakeholders $(\mathrm{Qu}, 2009)$. Being external oriented, these companies acknowledge the potential increase in stakeholders' expectations towards CSR following regulatory efforts in Malaysia and the importance of meeting their needs in order to create continuous superior performance for their companies. Failure to communicate their CSR initiatives could lead to withdrawal of support from the stakeholders and consequent negative impact on firm performance. In response to this change in market environment, companies engaged in market-oriented behaviour are more likely to increase their CSR reporting.

Table 7: Multiple Regression Results for Mediating Effect of CSR

\begin{tabular}{|l|l|l|l|l|l|c|}
\hline & $\mathbf{2 0 0 6}$ & & $\mathbf{2 0 0 7}$ & & $\mathbf{2 0 0 8}$ & Beta \\
\hline Constant & Beta & t-value & Beta & t-value & t-value \\
\hline LEV & -0.010 & -0.189 & 0.003 & 0.051 & 0.005 & 0.091 \\
\hline SIZE & $-0.396^{* * *}$ & -6.404 & $-0.314 * * *$ & -5.071 & $-0.321 * * *$ & -5.330 \\
\hline MO & $0.331 * * *$ & 5.028 & $0.394 * * *$ & 5.992 & $0.358^{* * *}$ & 5.453 \\
\hline CSR & -0.106 & -1.786 & -0.082 & -1.338 & -0.118 & -1.966 \\
\hline Adj. $\mathbf{R}^{\mathbf{2}}$ & $0.255^{* * *}$ & 3.276 & $0.199 * * *$ & 3.030 & $0.261 * * *$ & 4.056 \\
\hline F & 0.266 & & 0.256 & & 0.289 & \\
\hline
\end{tabular}

Coefficient for each variable is shown with t values in parentheses. * Significant at 10 per cent level (1-tailed test);

$* *$ Significant at 5 per cent level (1- tailed test); *** Significant at 1 per cent level (1-tailed test)

Results in Table 7 reveals the effects on RET when MO and CSR are entered into the regression model simultaneously. The results for the three years indicate that only CSR has significant effect on RET while MO has insignificant effect on RET. As such, condition 4 is satisfied in testing the mediation effect of CSR. However, as condition 3 has not been satisfied, the overall results indicate that CSR does not mediate the relationship between $\mathrm{MO}$ and RET. Hence, H3 is rejected. A possible explanation is that while companies acknowledge the strategic value of CSR in enhancing firm performance, such strategy has not been effectively integrated into the overall business strategies. This is consistent with the view that companies in developing countries tend to implement their strategies on a piecemeal basis. These results highlight that while market-oriented companies are more likely to meet the relevant stakeholders' needs through their CSR initiatives, the positive impact on firm performance can only be achieved if MO and CSR strategies are well integrated into the firm's overall strategies and decisions.

\section{CONCLUSION AND LIMITATIONS}

This study examines the effect of CSR disclosure and MO on firm performance as well as the mediating effect of CSR on the relationship between MO and firm performance. The results revealed significant positive relationships between the extent of CSR disclosure and RET. These results contribute to the corporate disclosure literature by providing new evidence that CSR activities and disclosure are important business strategies in creating continuous superior performance for organisations. This is in line with the view that organisations need to develop a stakeholder orientation particularly in an environment of increasing pressure on organisations to increase their social responsibilities. The stakeholder orientation recognises the importance of addressing the demands of multiple stakeholder groups. Disclosure of companies' CSR initiatives in annual reports have increasingly been used in communicating CSR initiatives to the relevant stakeholders. This in turn strengthened stakeholder relations and support for the organisations which consequently enhance firm performance.

The significant positive relationship between MO and CSR indicate that market-oriented companies are integrating CSR activities into their business strategies. These results further corroborate the inference that CSR is a stakeholder obligation and being external oriented, these companies are more likely to recognise the importance of CSR and incorporate CSR initiatives into their overall strategies. However, the insignificant mediating effect of CSR on the relationship between MO and firm performance indicate that MO and CSR strategies have not been effectively integrated in creating a synergistic effect that can bolster firm performance. 
In summary, the findings in this study suggest that MO and CSR are two important strategies that can drive performance-related behaviours in organisations in creating continuous superior performance. These findings have practical implications to organisations in developing and integrating their CSR activities and MO strategies as a tool to enhance firm performance, regulatory bodies in promoting and improving CSR and corporate transparency, other policy makers in strengthening capital market environment, to investment community and other stakeholders who rely on corporate disclosures in making their decisions.

Finally, there are some limitations in this study. First, this study focuses only on stock returns as a measure of firm performance. Future research may consider other measurement bases, such as accounting base, market base and corporate reputation. Second, this study focuses on CSR disclosures in companies' annual reports. Other forms of communication channels such as the company's web site, standalone sustainability-type reports, newspapers and in-house magazines have been used to communicate corporate social responsibility activities. Hence, future research may consider such disclosures. In addition, the level of MO has also been gauged from disclosure in annual reports only. Future research could also include data collection through more extensive interviews with preparers of the annual reports in order to gain more insights with regards to incorporating CSR activities and MO strategies as part of their overall business strategies.

\section{AUTHOR INFORMATION}

Roshayani Arshad is an Associate Professor at the Faculty of Accountancy, Universiti Teknologi MARA. She holds a PhD in accountancy from UiTM, Master of Accountancy from Glasgow University and is a graduate member of ACCA. She is currently the Head of Financial Reporting Research Centre and Research Fellow at the Accounting Research Institute and actively involved in various research projects. Her research interests include Financial Reporting, Corporate Disclosures, Corporate Social Responsibility, Reporting for Non-Profit Organisations and Corporate Governance. She has also written several books on financial accounting and reporting. E-mail: Roshayani@ @alam.uitm.edu.my (Corresponding author)

Siti Mariam Mansor is currently a lecturer at the Faculty of Accountancy, Universiti Teknologi MARA (UiTM) Perlis, Malaysia. She obtained her Master in Accountancy from Universiti Teknologi MARA in October 2011. Her current research interests include Corporate Social Responsibility and Market Orientation.

Rohana Othman is a Professor in Public Sector Accounting at the Faculty of Accountancy, Universiti Teknologi MARA (UiTM), Malaysia. She received her Doctorate in Accounting from the International Islamic University Malaysia, Kuala Lumpur. She also holds a Bachelor of Science (Bsc) in Accounting from Indiana State University, United States of America (USA) and a Master in Business Administration from University of Hartford, Connecticut, USA. Her current research interests include Public Sector Accountability and Governance, Islamic Finance, Earnings Management, Corporate Governance and Corporate Social Responsibility. E-mail: rohana799@salam.uitm.edu.my

\section{REFERENCES}

1. Brik, A. B., Rettab, B., and Mellahi, K. (2010). Market Orientation, Corporate Social Responsibility, and Business Performance. Journal of Business Ethics, 99, 307-324.

2. Chow, C. W., \& Wong-Boren, A. (1987). Voluntary Financial Disclosure by Mexican Corporations. The accounting review, 62 (3 (July), 533-541.

3. Deegan, C., Rankin, M., and Tobin, J. (2002). An examination of the corporate social and environmental disclosures of BHP from 1983-1997: a test of legitimacy theory. Accounting, Auditing and Accountability Journal, 15(3), 312-343.

4. Deegan, C. \& Rankin, M. (1996). Do Australian companies report environmental news objectively? An analysis of environmental disclosures by firms prosecuted successfully by the Environmental Protection Authority. Accounting, Auditing \& Accountability Journal, 9(2), 50-67.

5. $\quad$ Freeman, R.E. (1984). Strategic management: A stakeholder approach. Boston: Pitman Publishing.

6. Galbreath, J. (2010). The impact of strategic orientation on corporate social responsibility. International Journal of Organizational Analysis, 18(1), 23-40. 
7. Galbreath, J. (2008). Building corporate social responsibility into strategy. European Business Review 21(2), 109-127.

8. Gray,R., Kouhy, R. \& Lavers, S. (1995). Corporate social and environmental reporting: A review of the literature and a longitudinal study of UK disclosure accounting. Auditing and Accountability Journal, 8(2), 47-77.

9. Griffin, J.J. and Mahon, J.F. (1997), The corporate social performance and corporate financial performance debate, Business and Society, 36(1), 5-31.

10. Guthrie, J., and Parker, L. (1989). Corporate social reporting: rebuttal of legitimacy theory. Accounting and Business Research, 19(76), 343-352.

11. Hackston, D., Milne, D.M.., (1996). Some determinant of social and environmental disclosures in the New Zealand companies, Accounting, Auditing and Accountability Journal 9 (1), 77-108.

12. Haniffa, R.M. \& Cooke, T.E. (2005). The impact of culture and governance on corporate social reporting. Journal of Accounting and Public Policy, 24, 391-430.

13. Iwata, H., and Okada., K. (2011), "How does environmental performance affect financial performance? Evidence from Japanese manufacturing firms", Ecological Economics 70, 1691-1700.

14. Kim, Y. (2003). How will market orientation and environment and firm's character influence performance. Cross Cultural Management, 10(4), 71-88.

15. Kirca, A.H., Jayachandran, S. \& Bearden, W.O. (2005). Market orientation: A meta-analytic review and assessment of its antecedents and impact on performance. Journal of Marketing, 69(2), 24-41.

16. Kohli, A.K., Jaworski, B.J. \& Kumar, A. (1993). MARKOR: A measure of market orientation. Journal of Marketing Research, 30(4), 467-477.

17. Kohli, A.K. \& Jaworski, B.J. (1990). Market orientation: The construct, research propositions, and managerial implications. Journal of Marketing, 54(2), 1-18.

18. KPMG: 2005, KPMG International Survey of Corporate Responsibility Reporting 2005 (KPMG Global Sustainability Services: Amsterdam), http://www.kpmg.org

19. Maignan, I., Ferrell, O.C. and Farrell, L. (2005), A stakeholder model for implementing social responsibility in marketing, European Journal of Marketing, 39(9/10), 956-77.

20. Margolis, J. D., Walsh, J. P., (2003). Misery loves companies: Rethinking social initiatives by business, Administrative Science Quarterly, 48, 655-689.

21. Mavondo, F. T. \& Farrell, M. A. (2000). Market orientation: Are there differences between business marketers and consumers marketers?. Australian Journal of Management, 25(2), 223-244.

22. Narver, J. C. \& Slater, S. F. (1990). The effect of a market orientation on business profitability. Journal of Marketing, 54(4), 20-35.

23. Nazli, M. G., and Weetman, P. (2006), "Perpetuating traditional influences: voluntary disclosure in Malaysia following the economic crisis", Journal of International Accounting, Auditing \& Taxation, 15, 226-248.

24. Piercy, N. F. \& Lane, N., (2009). Corporate social responsibility: Impacts on strategic marketing and customer value. The Marketing Review, 9(4), 335-360.

25. Porter, M. E. (1996). What is Strategy?. Harvard Business Review, 74 (6), 54-61.

26. Qu, R. (2009). The impact of market orientation and corporate social responsibility on firm performance: Evidence from China. Asia Pacific Journal of Marketing and Logistics, 21(4), 570-582.

27. Smith, N.C., et. al (2005) Marketing consequences: stakeholder marketing and supply chain csr issues. France: INSEAD.

28. Sueyoshi, T., and Goto, M. (2011), "Measurement of a linkage among environmental, operational and financial performance in Japanese manufacturing firms: A use of Data Envelopmental Analysis with strong complementary slackness condition", European Journal of Operational Research 207, 1742-1753.

29. Tse, C.B., Sin, Y.M., Yau, H.M. \& Lee, S.Y. (2001), Relationship between market orientation and business performance: an empirical study in a Chinese business environment, Journal of Business Research.

30. Unerman, J. (2000). Methodological issues: Reflections on quantification in corporate social reporting content analysis. Accounting, Auditing \& Accountability Journal, 13(5), 667-690.

31. Wilmshurst, I.D., \& G.R. Frost (2000), The roles of accounting and the accountant in the environmental management system, Business Strategy and the Environment, 10,135- 47. 